University of Louisville

ThinkIR: The University of Louisville's Institutional Repository

Electronic Theses and Dissertations

8-2012

\title{
Analysis of microRNA microarray (MM chip) data for aging mice models.
}

Vikranth Shetty

University of Louisville

Follow this and additional works at: https://ir.library.louisville.edu/etd

\section{Recommended Citation}

Shetty, Vikranth, "Analysis of microRNA microarray (MM chip) data for aging mice models." (2012).

Electronic Theses and Dissertations. Paper 1318.

https://doi.org/10.18297/etd/1318

This Master's Thesis is brought to you for free and open access by ThinkIR: The University of Louisville's Institutional Repository. It has been accepted for inclusion in Electronic Theses and Dissertations by an authorized administrator of ThinkIR: The University of Louisville's Institutional Repository. This title appears here courtesy of the author, who has retained all other copyrights. For more information, please contact thinkir@louisville.edu. 


\title{
ANALYSIS OF MICRORNA MICROARRAY (MM CHIP) DATA FOR AGING MICE MODELS
}

\author{
By \\ Vikranth Shetty \\ B.S. in Mathematics and Statistics, \\ Osmania University, India, 2006
}

\author{
A Thesis \\ Submitted to the Faculty of the \\ School of Public Health and Information Sciences \\ University of Louisville \\ in Partial Fulfillment of the Requirements \\ for the Degree of \\ Masters of Science \\ Department of Bioinformatics and Biostatistics \\ University of Louisville \\ Louisville, Kentucky
}

August 2012 
Copyright 2012 by Vikranth Shetty

All rights reserved 
Analysis of MicroRNA Microarray (MM chip) data for Aging mice models

By

Vikranth Shetty

A Thesis Approved on

Aug. 2, 2012

Date

by the following Thesis Committee:

Dongfeng Wu, Thesis Director

Eugenia Wang

Shesh nath Rai 


\section{ACKNOWLEDGEMENTS}

My deepest gratitude goes first and foremost to Professor Dongfeng $\mathrm{Wu}$, my thesis advisor and Professor Shesh nath Rai, vice chair of the committee for their constant encouragement and guidance. They have walked me through all the stages of the writing of this thesis. Without their consistent and illuminating instruction, this thesis could not have reached its present form. Second, I would like to express my heartfelt gratitude to Professor Eugenia Wang, also one of my committee members, and her group for providing the data.

Last my thanks would go to my beloved family for their loving considerations and great confidence in me all through these years. I also owe my sincere gratitude to my friends and my fellow classmates who gave me their help and time in listening to me and helping me work out my problems during the difficult course of the thesis. 


\begin{abstract}
ANALYSIS OF MICRORNA MICROARRAY (MM CHIP) DATA FOR AGING MICE MODELS

Vikranth Shetty

August 2nd, 2012

The present experimental designs have unique challenges in the analysis of microRNA expression intensity levels. In this project, various Normalization techniques were discussed with different statistical techniques and their application in an analysis performed at the Genes Centre of aging on mice models. The project involved repeated measures over time, and the intra-subject correlation caused by the repeated measurements should be incorporated into the analysis, resulting in additional significant miRNAs. Collection of multiple samples from the same individuals over time from an experiment may have issues with the commonly used methodologies-these issues are discussed here. Mixed model approach is used here to see the difference between different normalized data with the raw data with repeated measurements.
\end{abstract}




\section{TABLE OF CONTENTS}

\section{PAGE}

ACKNOWLEDGMENTS

ABSTRACT

LIST OF TABLES

LIST OF FIGURES

iii

iv

$\mathrm{V}$

vi

CHAPTER

1. INTRODUCTION

2. MATERIALS AND METHODS 4

3. RESULTS AND DISCUSSION 10

4. CONCLUSIONS 29

$\begin{array}{ll}\text { REFERENCES } & 30\end{array}$

CURRICULUM VITAE 


\section{LIST OF TABLES}

TABLE

PAGE

1. Significant miRNA in Treatment, Age and Interaction using Quantile Normalization

2. Significant miRNA in Treatment, Age and Interaction using Raw data

3. Significant miRNA in Treatment, Age and Interaction except the intercept using Quantile Normalization

4. Significant miRNA in Treatment, Age and Interaction except the intercept using Raw data

5. Significant miRNA in Treatment and Interaction using Quantile Normalization

6. Significant miRNA in Treatment and Interaction using Raw data

7. Significant miRNA in Age and Interaction using Quantile Normalization

8. Significant miRNA in Age and Interaction using Raw data 


\section{LIST OF FIGURES}

FIGURE PAGE

1. Whole data procedure 2

2. Down regulation of CR mice in three miRNAs in brain 3

3. MM chip robotic machine 5

4. RT-qPCR Machine 6

5. Density plots for each age point -No normalization $\quad 12$

6. Density plots for each age point-Quantile normalization 13

7. Density plots for each age point in each plate in treatment group - No normalization

8. Density plots for each age point in each plate in treatment group - Quantile normalization

9. Density plots for all age points in each plate in Control group - No normalization

10. Density plots for all age points in each plate in Control group - Quantile normalization

11. Density plots for all age points in each plate in Treatment group - No normalization

12. Density plots for all age points in each plate in Treatment group - Quantile normalization

13. Cumulative Distribution associated with normalization technique and the raw data for Control group

14. Cumulative Distribution associated with normalization technique and the raw data for Treatment group 


\section{INTRODUCTION}

MicroRNA (miRNA) are small family of non-coding RNAs about 20 to 25 nucleotides in length that play a key role in regulating the gene expression in biological processes. miRNAs are coded by genes that are transformed into protein(1). They are processed from primary transcripts known as pri-miRNA to short stem loop structure called pre-miRNA and finally to function miRNA. In Simple words, miRNAs are small RNAs with a big role in gene regulation (1). The first miRNA family was discovered in Caenorhabditis elegans as genes that were required for the timed regulation of developmental events (1). All the miRNA genes have been documented in the MicroRNA Registry (http://www.mirbase.org).

miRNAs have various expression patterns and might regulate developmental and physiological processes. miRNAs are involved in post-transcriptional gene regulation in organisms ranging from plants to humans. Important roles are that comprise control of developmental timing, tissue growth, tumor suppression, cell

differentiation and apoptosis (1). Many miRNAs are highly expressed in certain organs or cell types and some are only expressed in certain stages during development (1). These regulations in expression patterns coordinate with their functions; therefore, much research has concentrated on the expression studies of miRNAs. Several studies have examined the role of miRNAs in various diseases such as aging (2) and cancer. The clinical understanding of the role of miRNAs in aging is growing very rapidly. There are several different techniques used to obtain the expression levels of miRNAs and include microarray analysis and TaqMan PCR from Applied Biosystems. 
This project was inspired by the research work regarding three key miRNAs that target $\mathrm{Bcl} 2$ protein, which causes the apoptosis of the cell in calorie restricted mice conducted at Gheens Centre of Aging, which is already published in Aging journal. The difference in this project is that we will use statistical methods to screen all miRNAs that may change with calorie restriction. The comparative expression of the miRNAs of interest was screened by miRNA microarrays (MM Chip) in brain samples of CR- and ad lib-fed mice. For comparative proteomic and miRNA expression analysis, 18 mice were divided equally into CR and Ad Lib populations across 3 age groups: 12, 24 and 28 months. All experiments were carried out in triplicate. The whole data structure is shown in the figure 1.

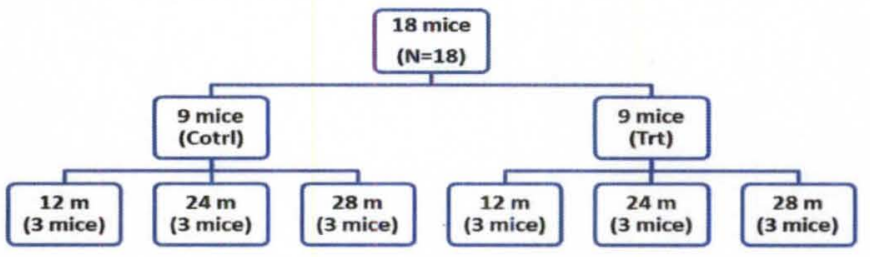

No. of Animals : 3(For each Age point)

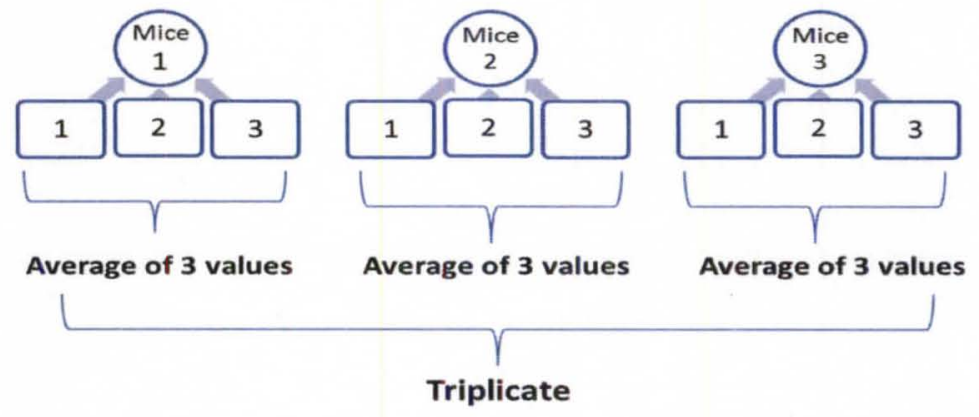

Figure 1. Whole data procedure

The three miRNAs, mmu-mir-181a-1*, mmu-mir-34a and mmu-mir-30e, exhibit the most significant down-regulation in brains of CR-fed mice, in an agedependent manner, compared to ad lib-fed mice(2) Figure 2. 


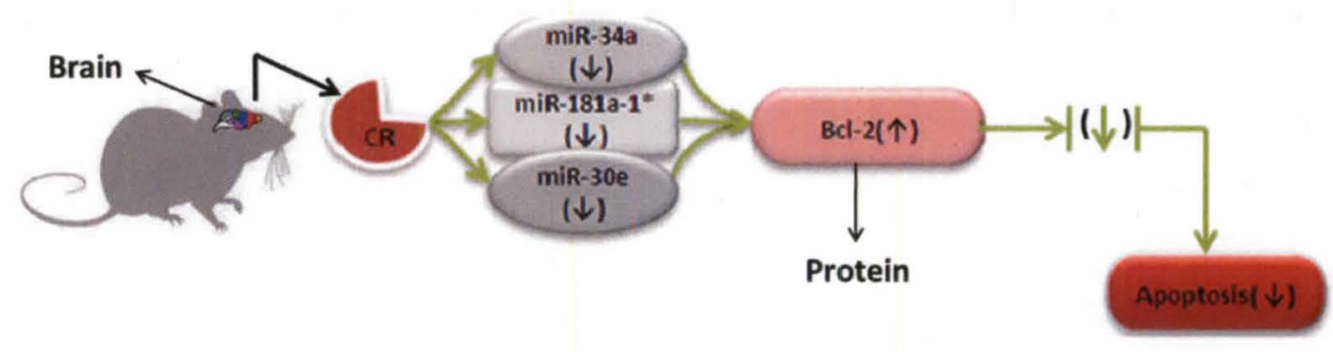

Figure 2.Down regulation of CR mice in three miRNAs in brain(2)

Initially MM chip method was used to find the miRNA expression levels for 361 miRNAs. Among them the three miRNAs mentioned above where found to be down regulated in $\mathrm{CR}$ brain and those three miRNAs targeting the $\mathrm{Bcl} 2$ protein(this was found using target prediction sites). In ad lib-fed mouse brain tissues Bcl-2 expression levels show an age- dependent decline. To confirm this qPCR analysis was done followed by the MM chip method.

The purpose of this study was to carry out different normalization techniques for the MM chip data for 361 miRNAs and to see which one is better among them. To consider the repeated measures within each age group without taking the average and see if we can find more significant miRNAs using repeated measurements along with the replicates in raw data and the normalized data. 


\section{MATERIALS AND METHODS}

\subsubsection{MicroRNA Microarray (MM chip) method}

Most commercially available microarrays are designed with prefixed templates of genes of general interest, allowing investigators little freedom of choice in attempting to focus gene screening. This is where the designer microarray came into existence as next generation of DNA chips, allowing individual investigators with a user-friendly do-it-yourself approach gene screening from designing the probe templates to data mining(3).

In this method the samples are first filled in tubes and then using a robotic machine where these different sample tubes are converted into a single plate. This plate is placed in one of the racks in the robotic machine and all the names for the individual samples in the plate are labeled in the system with all the required settings. When the machine is started the robotic device will pick the sample plate from the racks and will place it on the red area as shown in the figure 3 . The pointers used to print the blots will dip themselves into the samples and print those on the glass slide with nylon membrane on it (used to increase the signal). This printing process is repeated three times for each miRNA on the same plate. These dipping pointers are cleaned after printing each miRNA to avoid the technical error. Required number of glass slides are printed and then labeled accordingly.

After the printing is done the nylon membranes are removed from the glass plates and are kept in a bottle with 1-micro gram of RNA sample and run it overnight using cDNA coding. After this process, the nylon sheet with the printing spots 
matches up with sample and gives microRNA expression. A high-resolution scanner is used to scan those miRNA expression levels into digital images. Dr. Wangs lab developed a software program, Gene Analyzer, which accomplishes background subtraction, array normalization and quantification. Net intensity was derived from the whole cell area measurement, and corrected using mean intensity of ring background of surrounding spots.

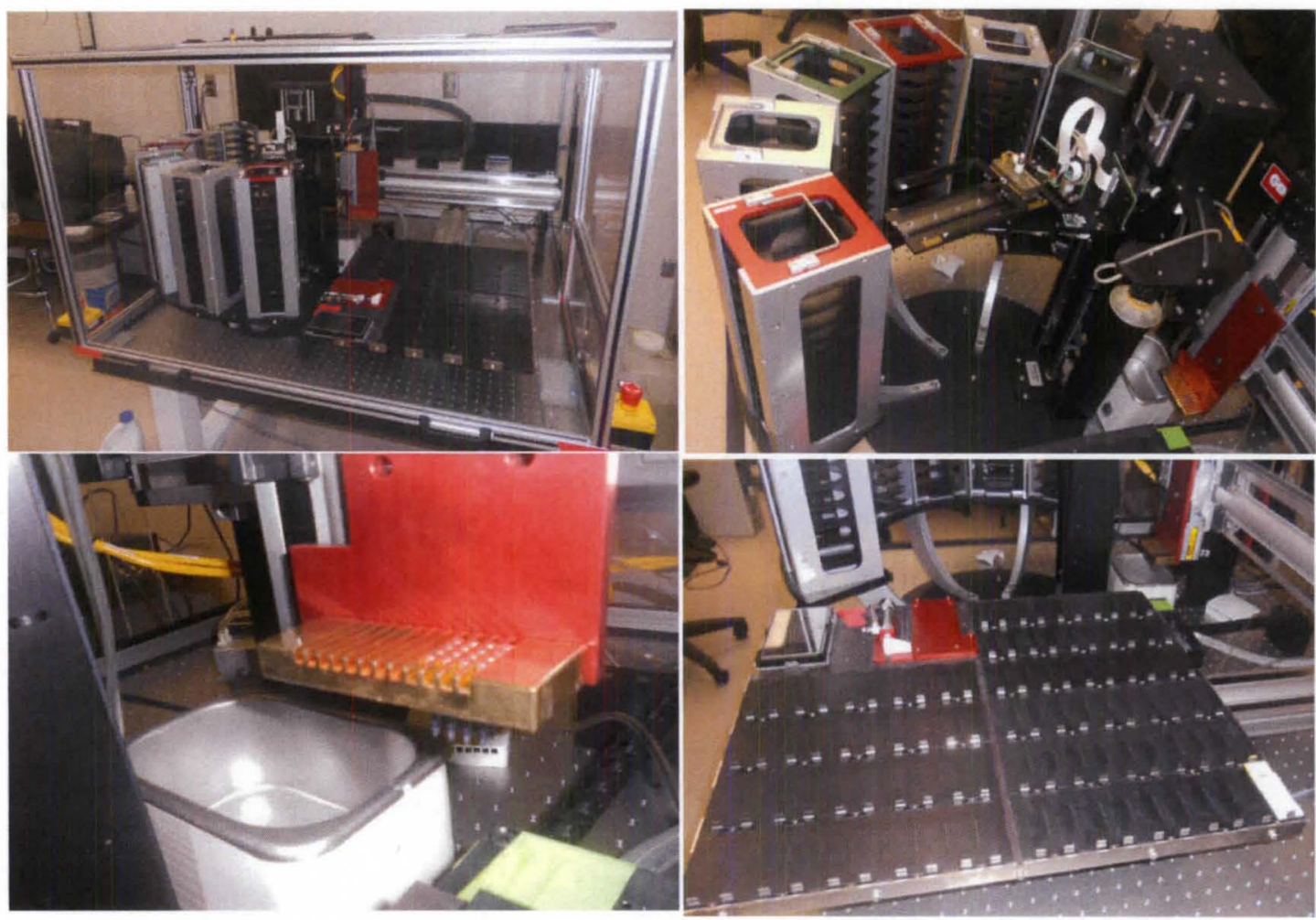

\subsubsection{Real time RT-qPCR method}

Real time PCR is one of the most sensitive and reliable quantitative methods for Gene expression analysis. One of the most important steps in relative quantitation experimental design is the selection of an appropriate endogenous control. Endogenous control is used for normalization. Any gene shown to be expressed at the same level in all the study samples can potentially be used as an endogenous control. 
In terms of accuracy and specificity, RT-qPCR has become the method of choice for measuring gene expression levels. However, the accuracy of result is largely dependent on the proper data normalization. The real-time machine is connected to a computer and necessary software on the computer is needed to run the real time PCR machine in real-time mode as shown in figure 4.

- Insert the plate with the samples into the machine

- Enter names for all reactions

- Enter the volume(sample added in the plate)

- Select the number of cycles

- Select detector(choosing which miRNA you want to analyze)

- Setup amplification conditions(Heating)

- $\quad$ Click start

- Adjust the threshold after the Analysis based on your amplications and Threshold Cycle.

- Standard Deviation will be higher if it is not well adjusted.

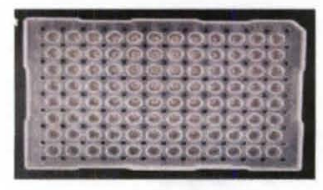

96-well plate

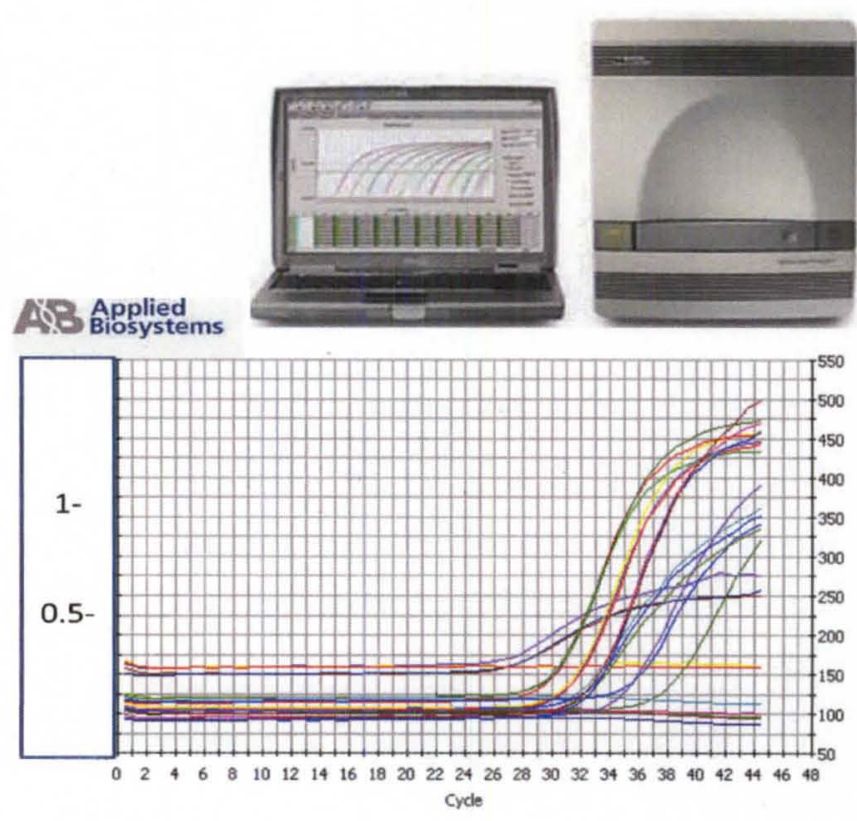

Figure 4.RT-qPCR Machine 


\subsection{Data Analysis Methods}

\subsubsection{Delta Ct method}

The Delta $\mathrm{Ct}$ method subtracts the expression levels of endogenous controls from the remaining miRNA expression intensity values. Nine endogenous controls were used few among them are $18 \mathrm{~S}$ rRNA1, bACTIN and GAPDH.

The formula representing this is:

$$
\Delta \mathrm{CT}=\mathrm{CT} \mathrm{T}^{\text {target }}-\mathrm{CT}^{\text {reference }}
$$

Where CT ${ }^{\text {target }}$ is the individual value of all the miRNA expressions in the sample and CT ${ }^{\text {reference }}$ is the endogenous control. The Delta $\mathrm{Ct}$ method is the most popular Normalization method due to the natural biologic motivation.

\subsubsection{Quantile Normalization}

The quantile normalization forces the distribution of $\mathrm{Ct}$ values to be the same across all the plates. The method takes the largest value and replaces it with the mean of the largest values, and then repeats for each subsequent data point.

The formula representing this is:

$$
q_{k}^{*}=\operatorname{proj}_{\mathbf{d}} \mathbf{q}_{k}=\frac{\mathbf{q}_{k} \cdot \mathbf{d}}{\mathbf{d} \cdot \mathbf{d}} \mathbf{d}=\frac{1}{\sqrt{M}} \sum_{m=1}^{M} q_{m k} d=\left(\frac{1}{M} \sum_{m=1}^{M} q_{m k}, \cdots, \sum_{m=1}^{M} q_{m k}\right)
$$

where

$$
\mathrm{d}=\left(\frac{1}{\sqrt{M}}, \cdots, \frac{1}{\sqrt{M}}\right) \cdot \mathrm{d}=\left(\frac{1}{\sqrt{M}}, \cdots, \frac{1}{\sqrt{M}}\right)
$$

and $q k$ is the $k$ th row of ordered intensity values. The intensity values are ordered for each plate independent of the other plates. The quantile normalization methodology is commonly used in the analysis of microarray expression values but the technique assumes that the distribution of the expression values is the same. 


\subsubsection{Rank invariant Normalization}

The virtual reference sample is created by averaging the content of the reference group (in differential analysis) or the first group of the group set (in gene analysis). All probes ranked between Low Rank $=50$ th and High Rank $=90$ th percentiles are considered. If the change of rank relative to the virtual reference is less than 0.05 , the probe is considered to be "rank invariant."

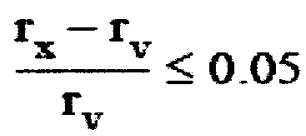

Where, $r_{x}$ is the individual miRNA expression miRNA and $r_{v}$ is the endogenous control.

If less than $2 \%$ of all probes are picked as rank invariant, Low Rank is gradually decreased until it reaches the $25^{\text {th }}$ percentile. Normalization coefficients are computed using iteratively reweighted least squares. This method is applied after the background normalization method described above.

\subsubsection{Coefficient of variation}

The empirical distribution (EDF) of the coefficient of variation is used to compare the various normalization techniques. We calculated the coefficient of variation for each miRNA over all the plates. Let $\mathrm{K}$ be the total number of miRNAs then the coefficient of variation is

$$
C V_{k}=\frac{\operatorname{sd}(C t)}{\operatorname{mean}(C t)}, k=1,2, \ldots, K
$$

The empirical distribution of the coefficient of variation is created by using 


$$
\tilde{F}=\frac{1}{K} \sum_{k=1}^{K} I\left\{C V_{k} \leq t\right\}
$$

\subsubsection{Mixed model}

A mixed model was constructed to consider the repeated sampling. Let $j=1,2$ be the two different groups 1 corresponds to control group(AD) and 2 corresponds to the Treatment group(CR). Let $t=1,2,3$ be three time points 1 corresponds to 12 months, 2 corresponds to 24 months and 3 corresponds to 28 months. Let $l=1,2,3$ be the repeated measures for each individual(mice). Let $k=1,2,3$ be the repeated measurements for each time point. The following represent the model for each individual miRNA( $\mathrm{n}=361)$.

$$
=\alpha+\beta+Y \quad+\eta \quad)+
$$

Where,

$\alpha$ is overall mean

is the effect on group $j$

is the effect of time point in group $j$

is the residual term

$\alpha, \beta, \gamma, \eta$ are the unknown parameters that need to be estimated. 


\section{RESULTS AND DISCUSSION}

Three Normalization techniques have been used for this project 1). Delta $\mathrm{Ct}$ method, 2). Rank invariant method and 3). Quatile normalization method. R software was used to carry out all the analysis.

The Delta $\mathrm{Ct}$ method: This method is very popular and is a widely used normalization technique for Real time qPCR experiments. In this method, endogenous control is subtracted from the target gene to get the normalized expression value, this works well because the endogenous control in qPCR experiments is always less than the target genes. However for the MM chip data used in this project the data was already kind of normalized with the ring back ground intensity using software. The endogenous controls are expressed almost in the same range as target miRNA genes. Therefore the normalized values using the Delta $\mathrm{Ct}$ method are negative. So this method is not applicable to this method.

Rank invariant normalization: This method is similar to Delta Ct method since it uses the endogenous control to normalize the data. When we use this method we again get negative values after normalization. So this method is not applicable for our data.

Quantile normalization: This method worked well because it forced the distribution of all the plates to be the same. For this method endogenous control is not used as discussed in the methods section. By looking at the density plots below(Figure 5 - 12)

for the control and the treatment between raw data and the quantile normalization at each age point in all the plates it clearly shows that quantile normalization is 
consistent in all plates without any variation within the age groups and plates compared to raw data.

From the cumulative distribution graph in Figure $14 \& 13$. It is clear that the quantile normalization is better than the raw data but there is no huge difference between them this is because the data which we are using as raw data in this project is already kind of normalized so we are not able to see much difference between these two methods. If actual raw data was used, quantile normalization would be much higher in cumulative distribution graph. 

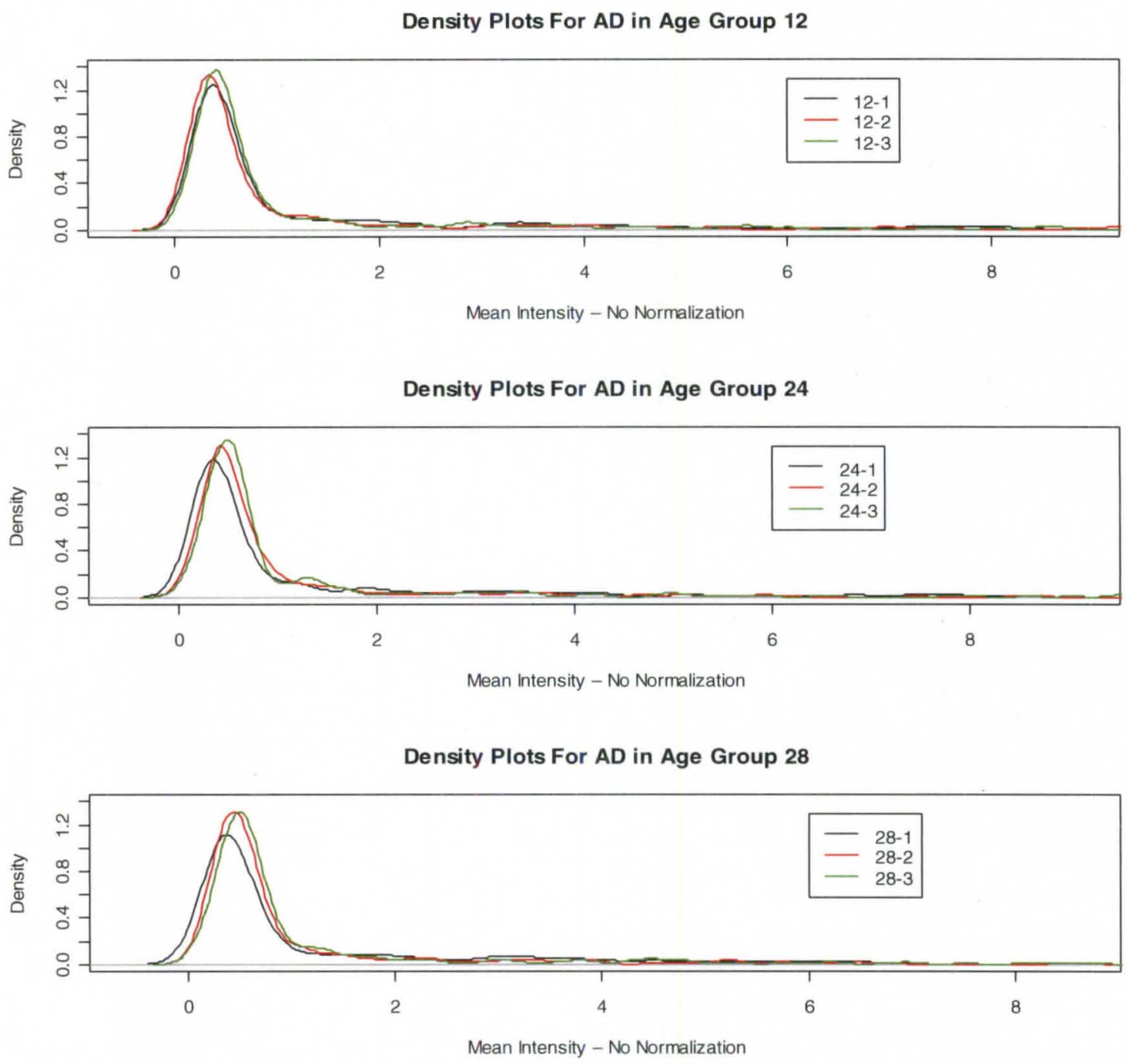

Figure 5. Density plots for each age point in each plate in Control group-No normalization 


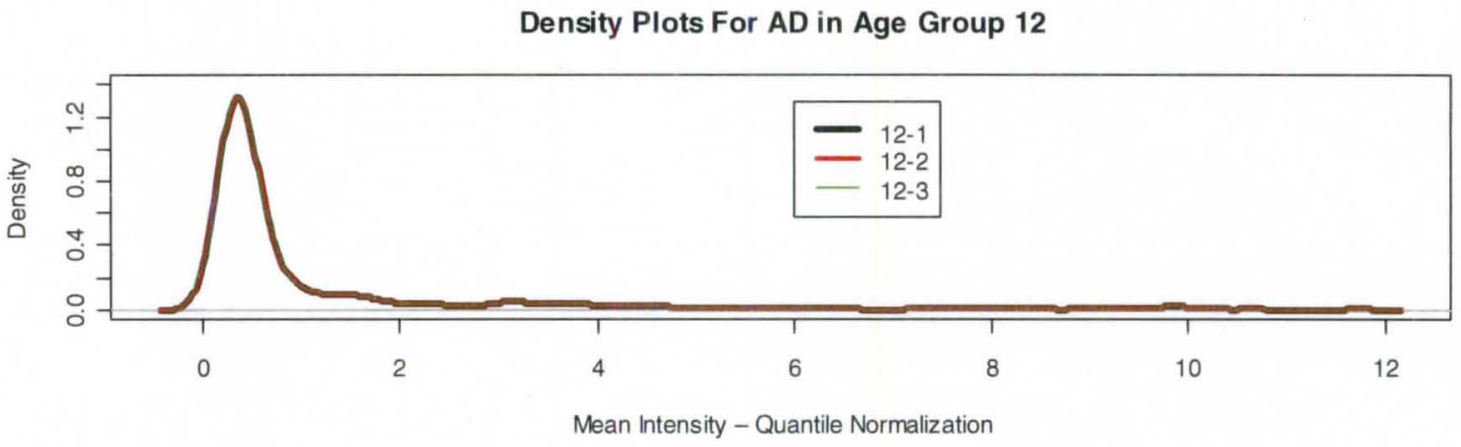

Density Plots For AD in Age Group 24

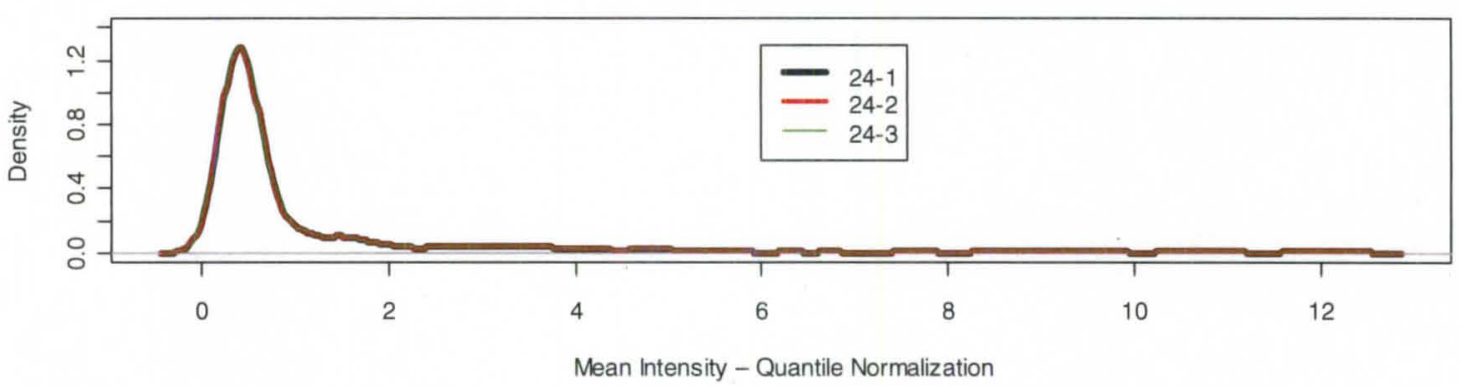

Density Plots For AD in Age Group 28

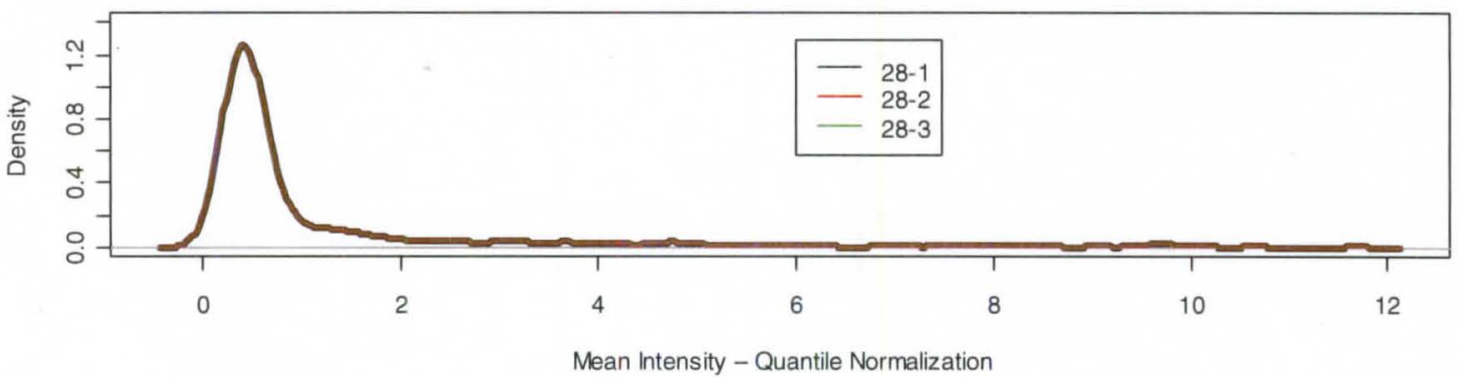

Figure 6. Density plots for each age point in each plate in Control group - Quantile normalization 
Density Plots For CR in Age Group 12

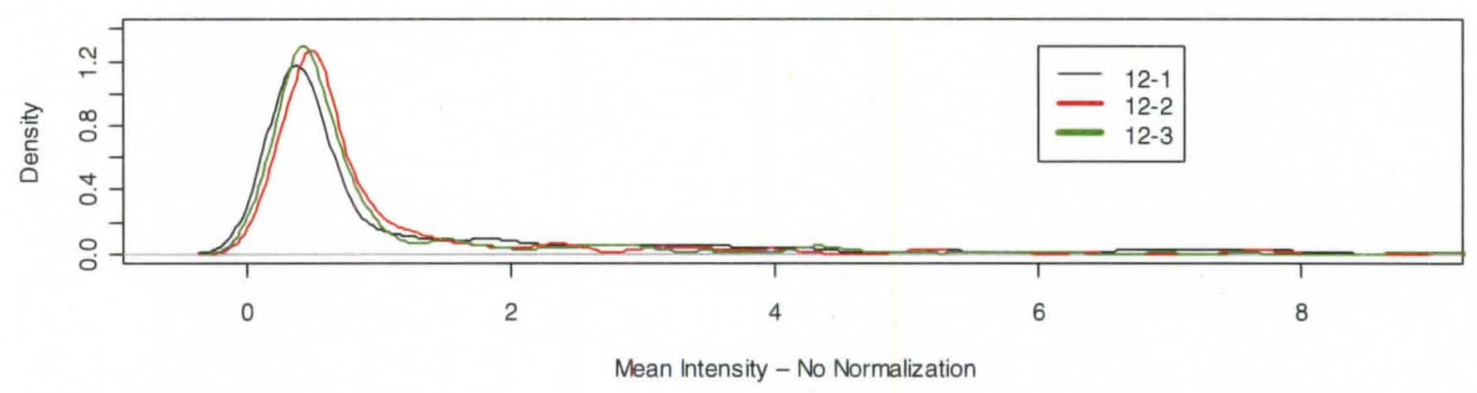

Density Plots For CR in Age Group 24

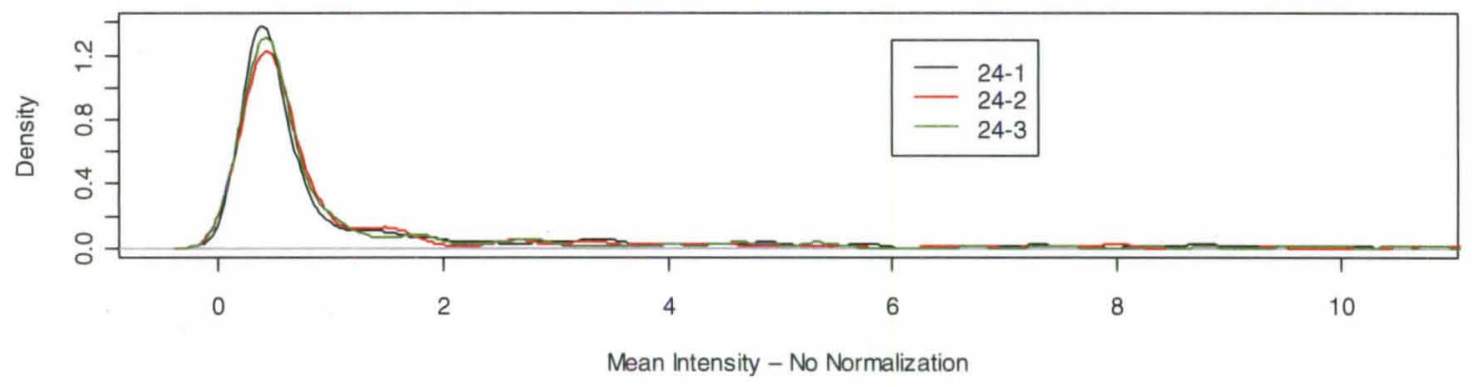

Density Plots For CR in Age Group 28

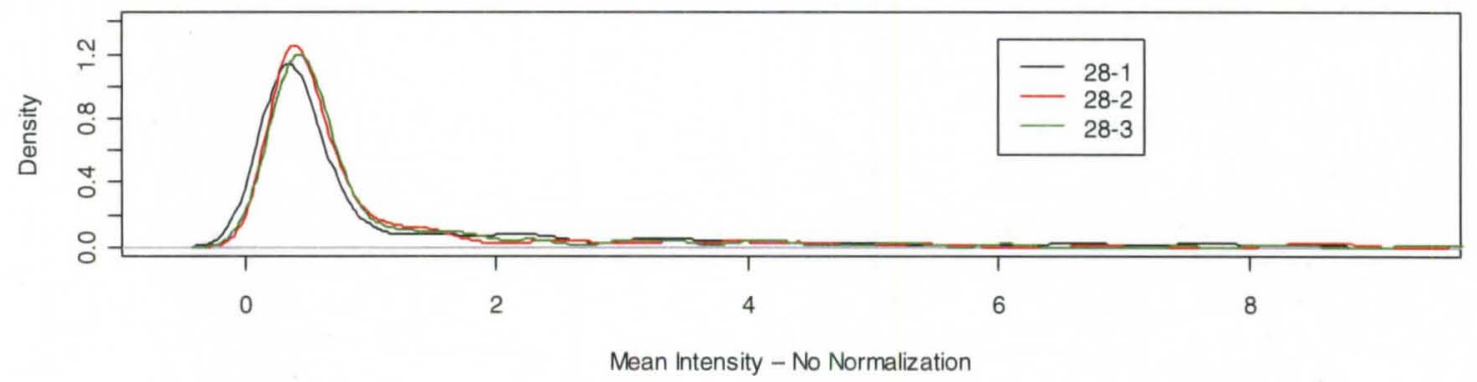

Figure 7. Density plots for each age point in each plate in treatment group - No normalization 


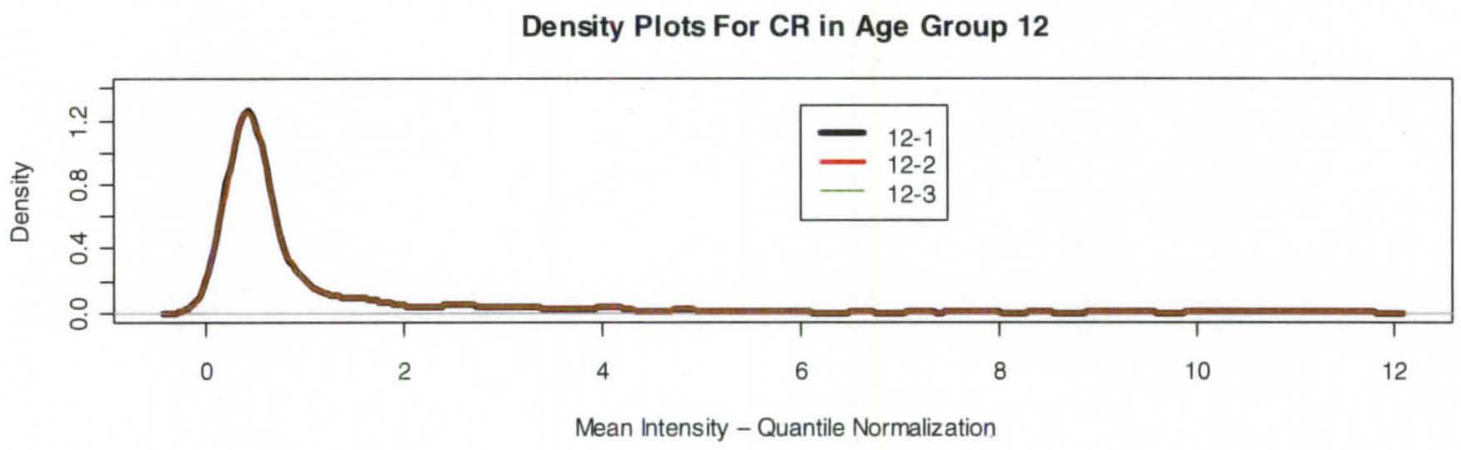

Density Plots For CR in Age Group 24

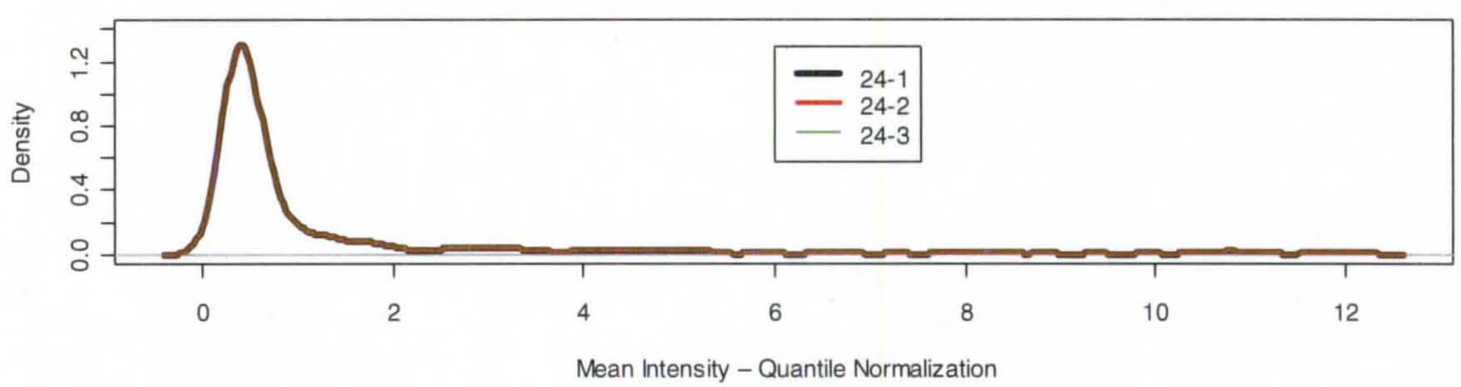

Density Plots For CR in Age Group 28

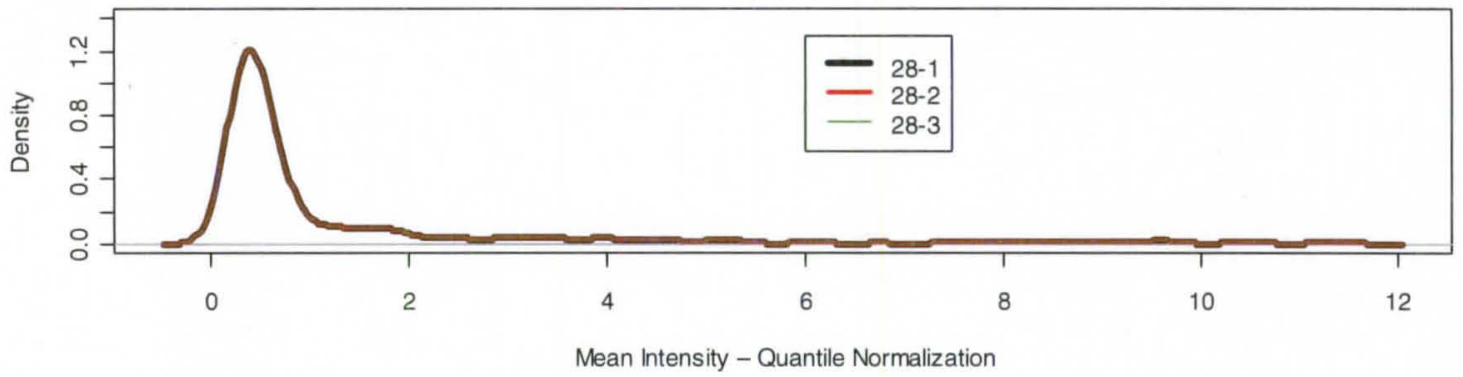

Figure 8. Density plots for each age point in each plate in treatment group - Quantile normalization 


\section{Density Plots For AD}

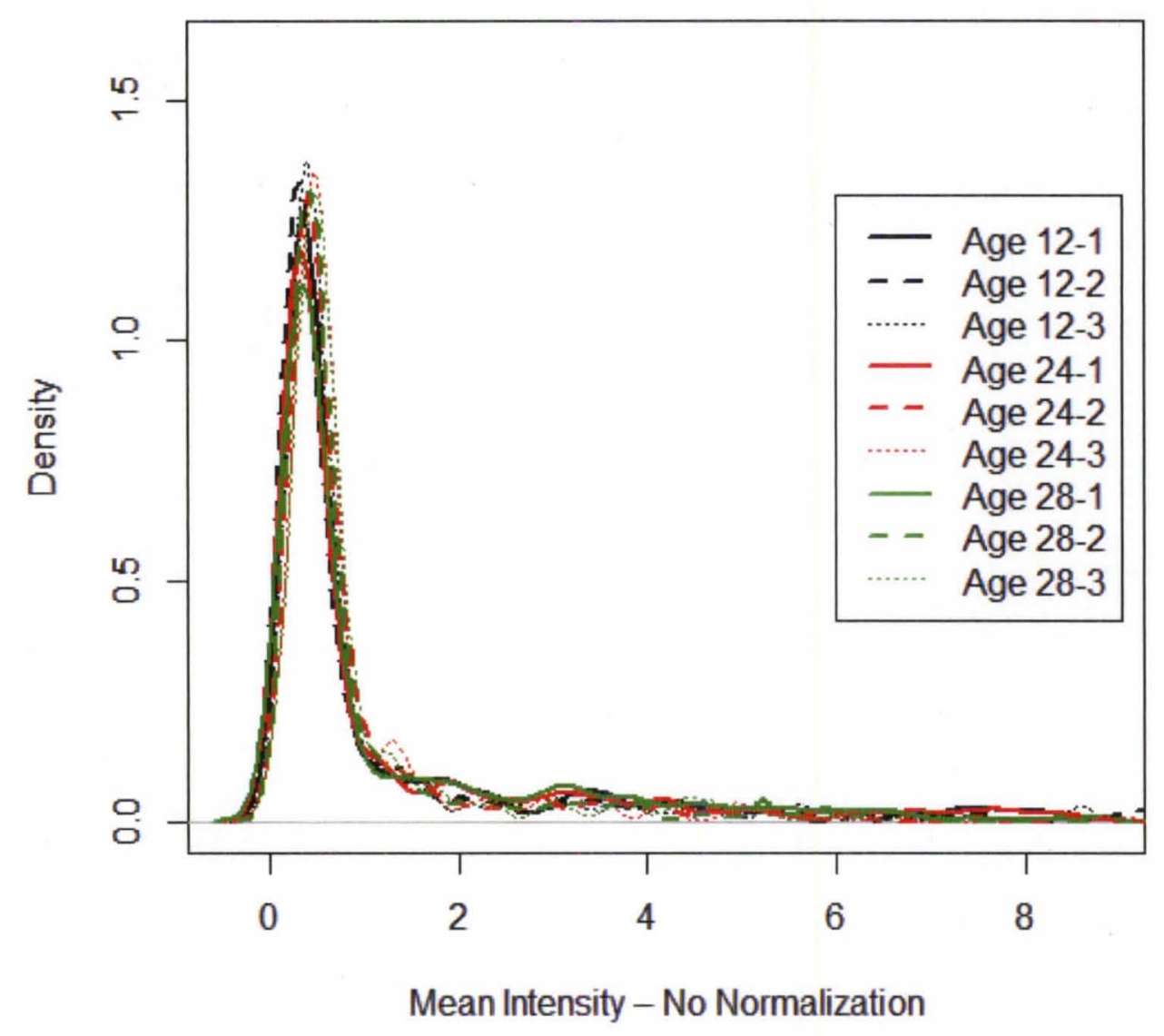

Figure 9. Density plots for all age points in each plate in Control group - No normalization 


\section{Density Plots For AD}

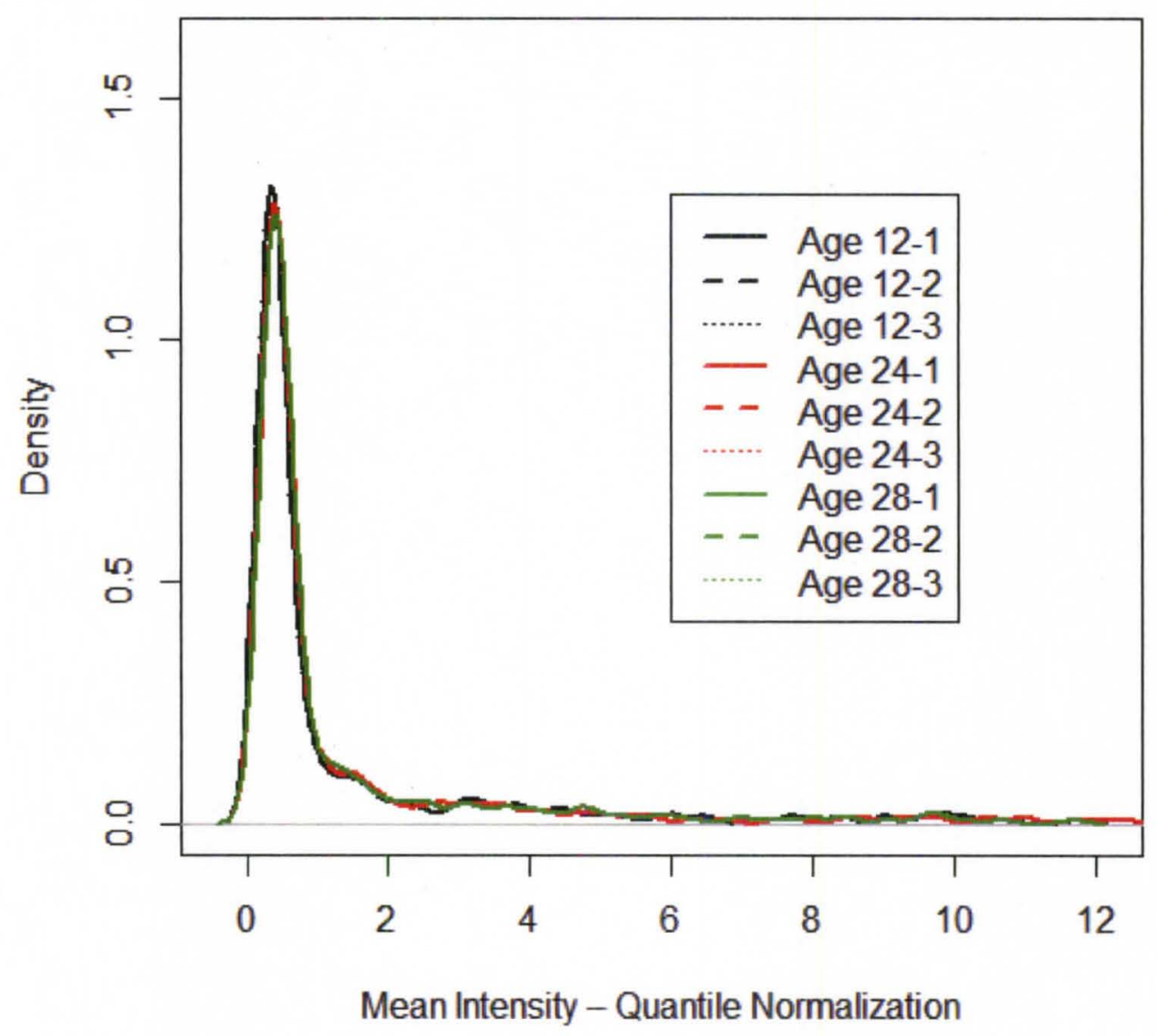

Figure 10. Density plots for all age points in each plate in Control group - Quantile normalization 


\section{Density Plots For CR}

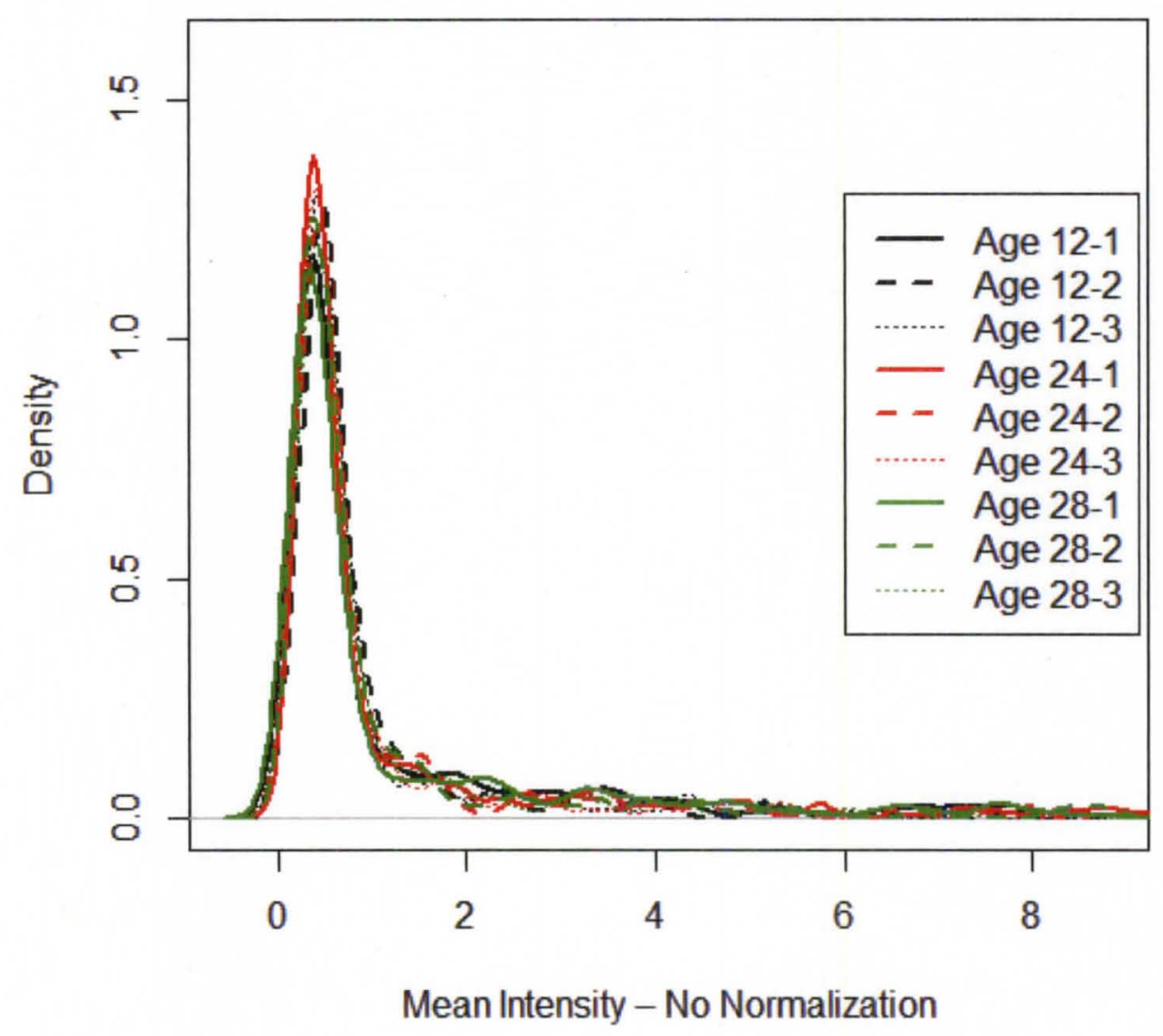

Figure 11. Density plots for all age points in each plate in Treatment group - No normalization 


\section{Density Plots For CR}

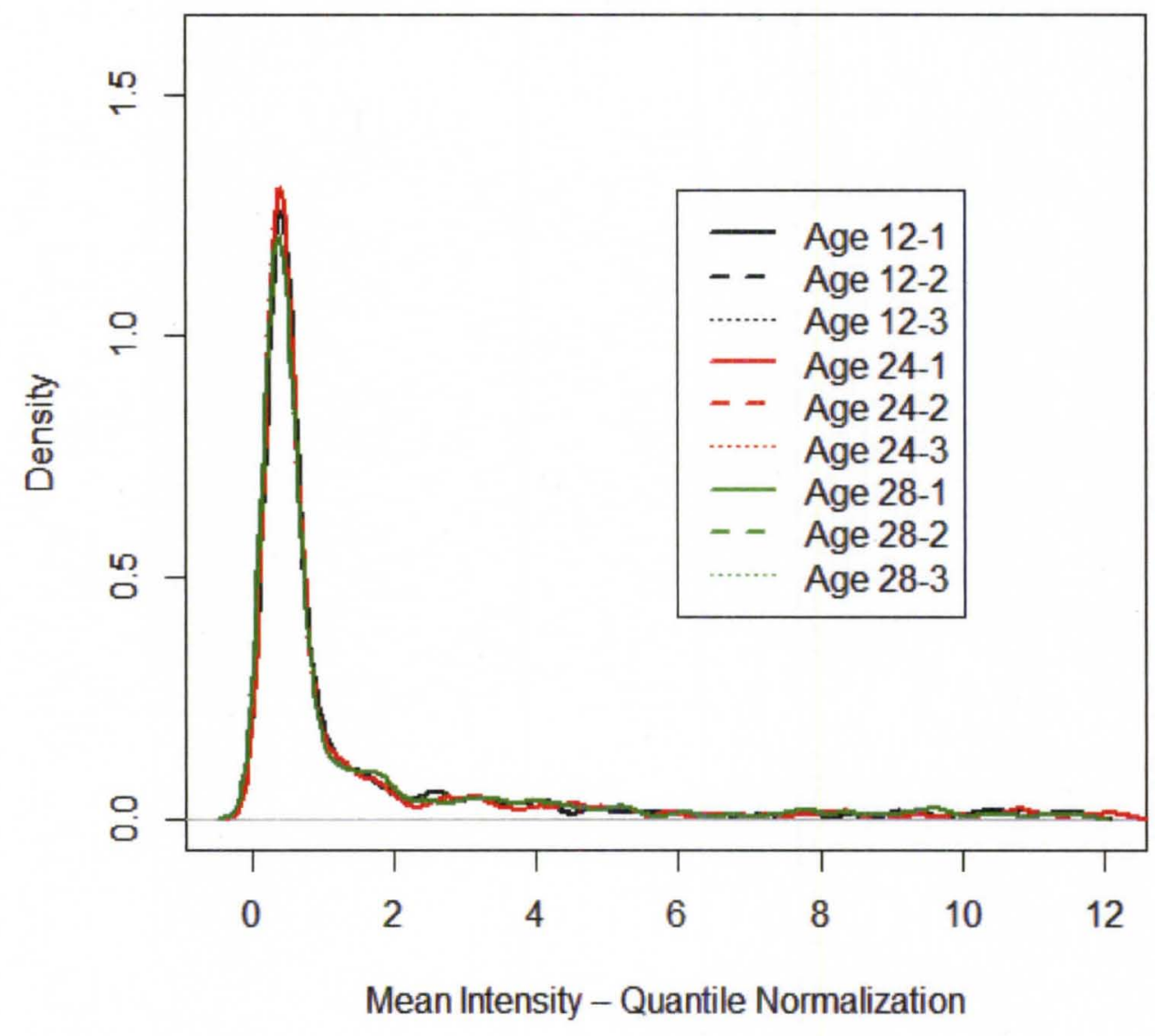

Figure 12. Density plots for all age points in each plate in Treatment group - Quantile normalization 


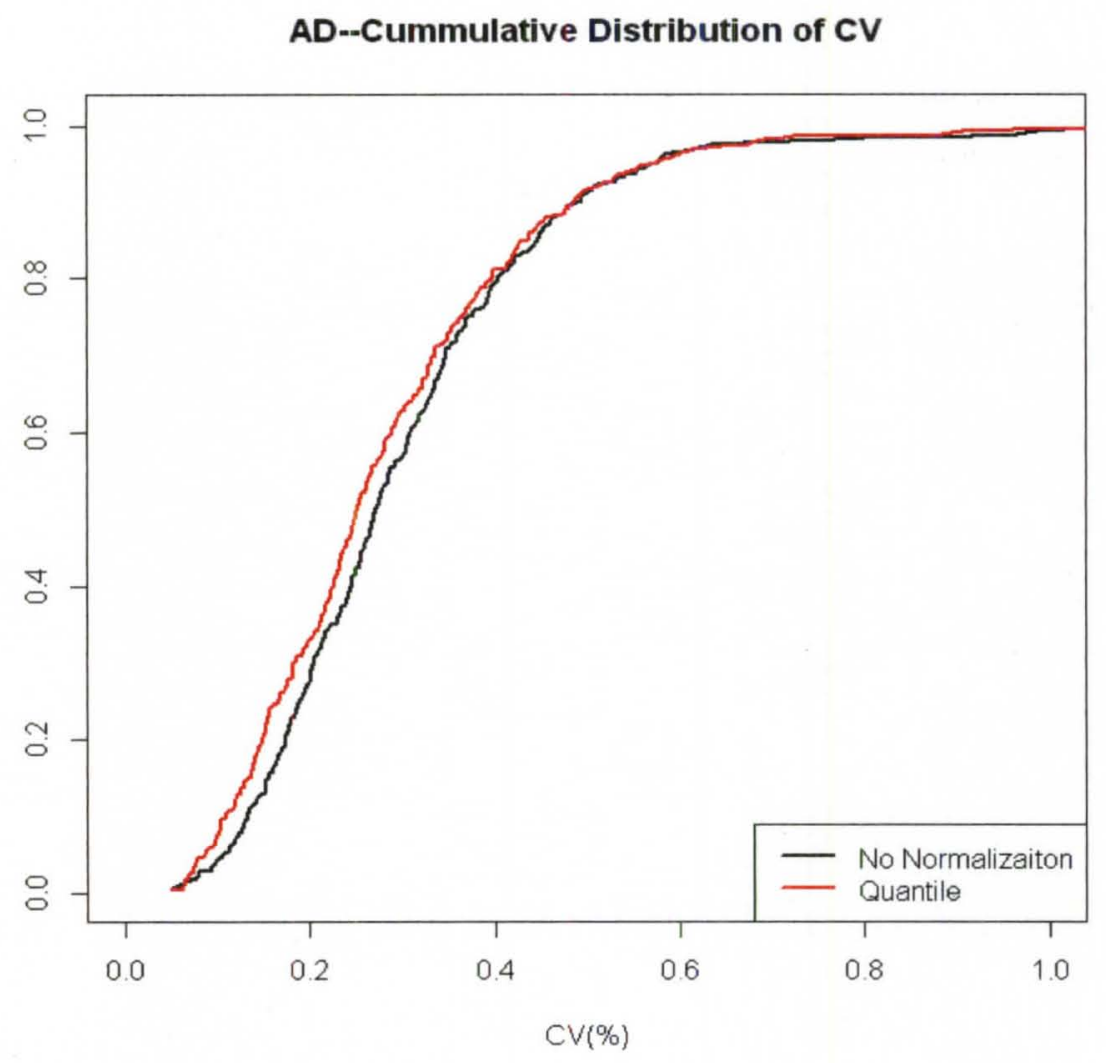

Figure 13. Cumulative Distribution associated with normalization technique and the raw data for Control group 


\section{CR--Cummulative Distribution of CV}

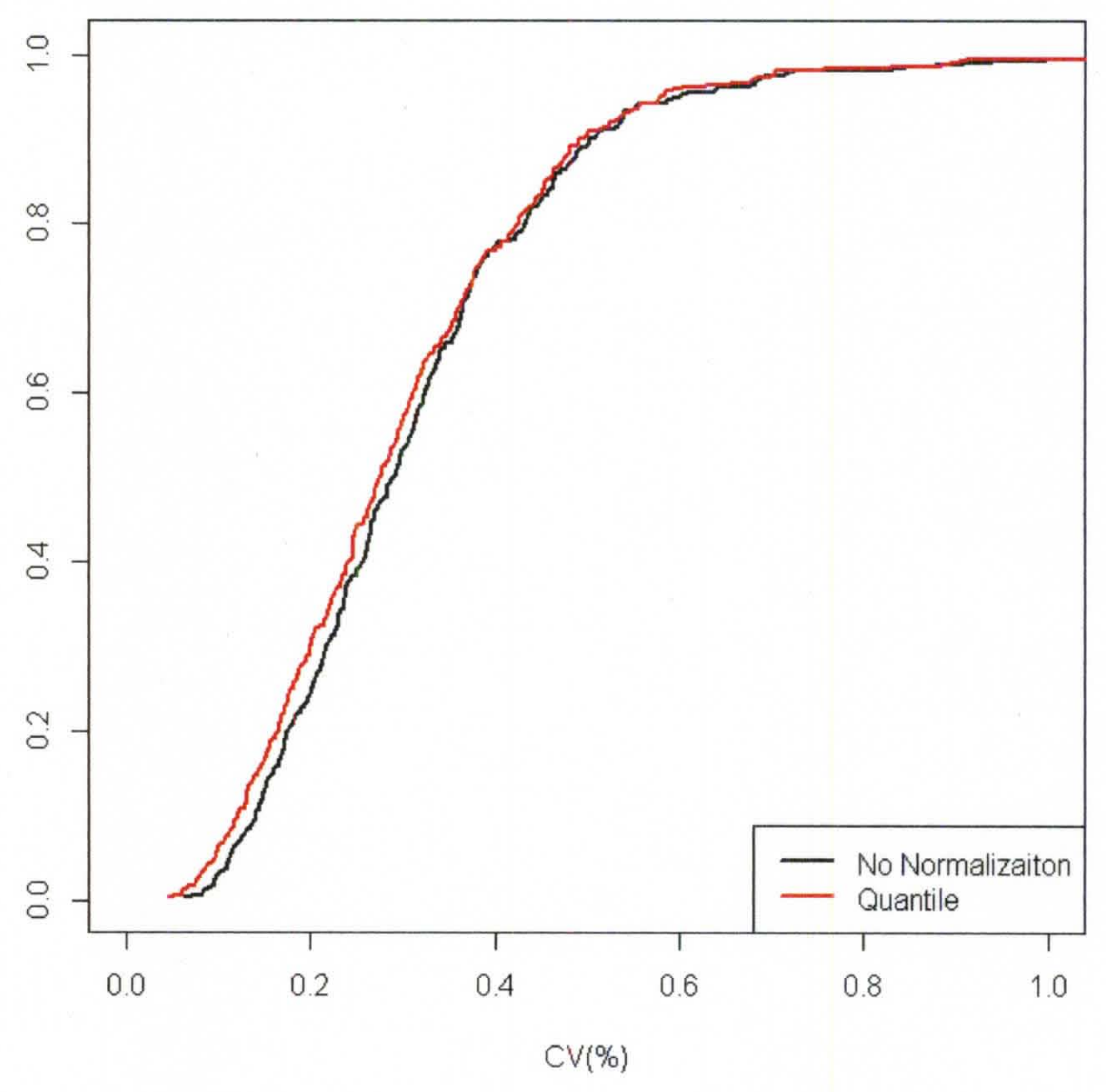

Figure 14. Cumulative Distribution associated with normalization technique and the raw data for Treatment group 


\section{Mixed model for replicates:}

Most of the biologists use the mean/average of the repeated measures for doing the data analysis. By doing this you may not find more miRNAs significant. So here we considered using all the replicates for the analysis. We found 8 miRNAs which are significant in all the coefficients and p-values are below $<0.001$ which are highly significant using the quantile normalization (Table 1.) and we found 6 miRNAs which are significant in all the coefficients and p-values are below $<0.001$ which are highly significant using raw data (Table 2.) that is $10 \%$ more miRNAs. We found 1 miRNAs which are significant in both the methods (Table 2. \& 3) and pvalues are below $<0.001$ which are highly significant. Interestingly, We found only 3 miRNAs which are significant in treatment and interaction term using quantile normalization (Table 5.) but whereas we found 14 miRNAs which are significant in treatment and interaction term using raw data (Table 6.) and the p-value here are around 0.03 , here we didn't adjust the p-values using multiple adhoc if we do it then you may not find these many miRNAs using raw data which would be our future research. 


\begin{tabular}{|l|c|c|c|c|}
\hline \multicolumn{1}{|c|}{ NAME } & $\begin{array}{c}\hat{\boldsymbol{\alpha}} \\
\text { (SE) }\end{array}$ & $\begin{array}{c}\hat{\boldsymbol{\beta}} \\
\text { (SE) }\end{array}$ & $\begin{array}{c}\hat{\mathbf{Y}} \\
\text { (SE) }\end{array}$ & $\begin{array}{c}\hat{\boldsymbol{\eta}} \\
\text { (SE) }\end{array}$ \\
\hline mmu-miR-148a & 4.98 & -2.08 & -0.06 & 0.10 \\
& $(0.3556)$ & $(0.4236)$ & $(0.0134)$ & $(0.0189)$ \\
\hline mmu-miR-127 & 2.94 & -1.99 & -0.064 & 0.088 \\
& $(0.3715)$ & $(0.523)$ & $(0.0165)$ & $(0.0234)$ \\
\hline mmu-miR-135a & 3.63 & -0.93 & -0.037 & 0.036 \\
& $(0.265)$ & $(0.368)$ & $(0.0116)$ & $(0.0164)$ \\
\hline mmu-miR-146 & 3.54 & -1.24 & -0.030 & 0.053 \\
& $(0.2287)$ & $(0.3149)$ & $(0.0099)$ & $(0.0141)$ \\
\hline mmu-miR-293 & 2.36 & -1.57 & -0.038 & 0.07 \\
& $(0.4113)$ & $(0.5172)$ & $(0.0163)$ & $(0.0231)$ \\
\hline mmu-miR-129-3p & 4.43 & -1.42 & -0.04 & 0.054 \\
& $(0.4207)$ & $(0.5724)$ & $(0.0181)$ & $(0.0256)$ \\
\hline mmu-miR-380-3p & 0.76 & 0.64 & 0.018 & -0.022 \\
& $(0.1758)$ & $(0.2421)$ & $(0.0076)$ & $(0.0108)$ \\
\hline mmu-miR-294 & 0.92 & -0.58 & -0.016 & 0.027 \\
& $(0.2306)$ & $(0.2419)$ & $(0.0076)$ & $(0.0108)$ \\
\hline
\end{tabular}

Table 1. Significant miRNA in Treatment, Age and Interaction using Quantile Normalization. $\hat{\alpha}, \hat{\beta}, \hat{Y}$ and $\hat{\eta}$ are the coefficient values of intercept, treatment, age, and age*treatment respectively. The values in parenthesis are the standard error values for the given coefficient. 


\begin{tabular}{|c|c|c|c|c|}
\hline NAME & $\begin{array}{c}\hat{\boldsymbol{\alpha}} \\
\text { (SE) }\end{array}$ & $\begin{array}{c}\hat{\boldsymbol{\beta}} \\
\text { (SE) }\end{array}$ & $\begin{array}{c}\hat{\mathbf{\gamma}} \\
\text { (SE) }\end{array}$ & $\begin{array}{c}\hat{\boldsymbol{\eta}} \\
(\mathrm{SE})\end{array}$ \\
\hline mmu-miR-148a & $\begin{array}{c}4.88 \\
(0.3736)\end{array}$ & $\begin{array}{c}-2.19 \\
(0.4659)\end{array}$ & $\begin{array}{c}-0.06 \\
(0.0147)\end{array}$ & $\begin{array}{c}0.10 \\
(0.0208)\end{array}$ \\
\hline mmu-miR-127 & 2.95 & -1.95 & -0.06 & 0.09 \\
& $(0.3833)$ & $(0.5309)$ & $(0.0168)$ & $(0.0237)$ \\
\hline mmu-miR-146 & 3.60 & -1.25 & -0.03 & 0.05 \\
& $(0.2519)$ & $(0.3454)$ & $(0.0109)$ & $(0.0154)$ \\
\hline mmu-miR-294 & 0.94 & -0.55 & -0.02 & 0.02 \\
& $(0.2473)$ & $(0.2483)$ & $(0.0078)$ & $(0.0111)$ \\
\hline mmu-miR-129-3p & 4.42 & -1.35 & -0.04 & 0.05 \\
& $(0.4143)$ & $(0.562)$ & $(0.0177)$ & $(0.0251)$ \\
\hline mmu-miR-380-3p & 0.82 & 0.56 & 0.02 & -0.02 \\
& $(0.1454)$ & $(0.1988)$ & $(0.0063)$ & $(0.0089)$ \\
\hline
\end{tabular}

Table 2. Significant miRNA in Treatment, Age and Interaction using Raw data. $\hat{\alpha}, \beta$, $\hat{Y}$ and $\hat{\eta}$ are the coefficient values of intercept, treatment, age, and age*treatment respectively. The values in parenthesis are the standard error values for the given coefficient. 


\begin{tabular}{|c|c|c|c|c|}
\hline NAME & $\begin{array}{c}\hat{\alpha} \\
\text { (SE) }\end{array}$ & $\begin{array}{c}\hat{\beta} \\
(\mathrm{SE}) \\
\end{array}$ & $\begin{array}{c}\hat{\gamma} \\
\text { (SE) }\end{array}$ & $\begin{array}{c}\hat{\eta} \\
\text { (SE) }\end{array}$ \\
\hline mmu-let-7c & $\begin{array}{c}0.10 \\
(0.2349)\end{array}$ & $\begin{array}{c}0.84 \\
(0.3266)\end{array}$ & $\begin{array}{c}0.021 \\
(0.0103)\end{array}$ & $\begin{array}{c}-0.039 \\
(0.0146)\end{array}$ \\
\hline
\end{tabular}

Table 3. Significant miRNA in Treatment, Age and Interaction except the intercept using Quantile Normalization. $\hat{\alpha}, \beta, \hat{Y}$ and $\hat{\eta}$ are the coefficient values of intercept, treatment, age, and age*treatment respectively. The values in parenthesis are the standard error values for the given coefficient.

\begin{tabular}{|c|c|c|c|c|}
\hline NAME & $\begin{array}{c}\hat{\alpha} \\
\text { (SE) }\end{array}$ & $\begin{array}{c}\beta \\
\text { (SE) }\end{array}$ & $\begin{array}{c}\hat{Y} \\
\text { (SE) }\end{array}$ & $\begin{array}{c}\hat{\eta} \\
\text { (SE) }\end{array}$ \\
\hline mmu-let-7c & $\begin{array}{c}0.11 \\
(0.2132)\end{array}$ & $\begin{array}{c}0.78 \\
(0.2947)\end{array}$ & $\begin{array}{c}0.02 \\
(0.0093)\end{array}$ & $\begin{array}{c}-0.04 \\
(0.0132)\end{array}$ \\
\hline
\end{tabular}

Table 4. Significant miRNA in Treatment, Age and Interaction except the intercept using Raw data. $\hat{\alpha}, \beta, \hat{Y}$ and $\hat{\eta}$ are the coefficient values of intercept, treatment, age, and age*treatment respectively. The values in parenthesis are the standard error values for the given coefficient.

\begin{tabular}{|c|c|c|c|c|}
\hline NAME & $\begin{array}{c}\hat{\mathbf{\alpha}} \\
\text { (SE) }\end{array}$ & $\begin{array}{c}\hat{\boldsymbol{\beta}} \\
\text { (SE) }\end{array}$ & $\begin{array}{c}\hat{\mathbf{\gamma}} \\
(\mathrm{SE})\end{array}$ & $\begin{array}{c}\hat{\mathbf{n}} \\
(\mathrm{SE})\end{array}$ \\
\hline mmu-miR-669c & -0.074 & 0.29 & 0.014 & -0.017 \\
& $(0.1174)$ & $(0.166)$ & $(0.0052)$ & $(0.0074)$ \\
\hline mmu-miR-325 & 0.048 & 0.36 & 0.017 & -0.018 \\
& $(0.1406)$ & $(0.1967)$ & $(0.0062)$ & $(0.0088)$ \\
\hline mmu-miR-211 & 8.85 & -1.61 & -0.059 & 0.079 \\
& $(0.614)$ & $(0.8683)$ & $(0.0274)$ & $(0.0388)$ \\
\hline
\end{tabular}

Table 5. Significant miRNA in Treatment and Interaction using Quantile Normalization. $\hat{\alpha}, \hat{\beta}, \hat{Y}$ and $\hat{\eta}$ are the coefficient values of intercept, treatment, age, and age*treatment respectively. The values in parenthesis are the standard error values for the given coefficient. 


\begin{tabular}{|c|c|c|c|c|}
\hline NAME & $\begin{array}{c}\hat{\alpha} \\
(\mathrm{SE})\end{array}$ & $\begin{array}{c}\beta \\
(\mathrm{SE})\end{array}$ & $\begin{array}{c}\hat{\gamma} \\
(\mathrm{SE})\end{array}$ & $\begin{array}{c}\hat{\eta} \\
\text { (SE) }\end{array}$ \\
\hline mmu-miR-293 & $\begin{array}{c}2.34 \\
(0.4381)\end{array}$ & $\begin{array}{c}-1.40 \\
(0.5134)\end{array}$ & $\begin{array}{c}-0.03 \\
(0.0162)\end{array}$ & $\begin{array}{c}0.06 \\
(0.0229)\end{array}$ \\
\hline mmu-miR-27a & $\begin{array}{c}4.59 \\
(0.5445)\end{array}$ & $\begin{array}{c}-2.08 \\
(0.7095)\end{array}$ & $\begin{array}{c}-0.04 \\
(0.0224)\end{array}$ & $\begin{array}{c}0.09 \\
(0.0317)\end{array}$ \\
\hline mmu-miR-223 & $\begin{array}{c}0.59 \\
(0.1329)\end{array}$ & $\begin{array}{c}0.63 \\
(0.1879)\end{array}$ & $\begin{array}{c}0.00 \\
(0.0059)\end{array}$ & $\begin{array}{c}-0.02 \\
(0.0084)\end{array}$ \\
\hline mmu-miR-17-3p & $\begin{array}{c}0.40 \\
(0.1125)\end{array}$ & $\begin{array}{c}0.43 \\
(0.1582)\end{array}$ & $\begin{array}{c}0.00 \\
(0.005)\end{array}$ & $\begin{array}{c}-0.02 \\
(0.0071)\end{array}$ \\
\hline mmu-miR-216a & $\begin{array}{c}0.33 \\
(0.1107)\end{array}$ & $\begin{array}{c}0.40 \\
(0.1509)\end{array}$ & $\begin{array}{c}0.01 \\
(0.0048)\end{array}$ & $\begin{array}{c}-0.02 \\
(0.0067)\end{array}$ \\
\hline mmu-mi & $\begin{array}{c}0.31 \\
(0.1072)\end{array}$ & $\begin{array}{c}0.35 \\
(0.1513)\end{array}$ & $\begin{array}{c}0.00 \\
(0.0048)\end{array}$ & $\begin{array}{c}-0.02 \\
(0.0068) \\
\end{array}$ \\
\hline $\mathrm{mmu}$ & $\begin{array}{c}0.35 \\
(0.1216)\end{array}$ & $\begin{array}{c}0.52 \\
(0.1699)\end{array}$ & $\begin{array}{c}0.00 \\
(0.0054)\end{array}$ & $\begin{array}{c}-0.02 \\
(0.0076)\end{array}$ \\
\hline mmu-m & $\begin{array}{c}0.65 \\
(0.239) \\
\end{array}$ & $\begin{array}{c}1.11 \\
(0.3322)\end{array}$ & $\begin{array}{c}0.00 \\
(0.0105)\end{array}$ & $\begin{array}{c}-0.04 \\
(0.0148)\end{array}$ \\
\hline mmu-miR-667 & $\begin{array}{c}0.72 \\
(0.3252)\end{array}$ & $\begin{array}{c}1.71 \\
(0.4379)\end{array}$ & $\begin{array}{c}0.02 \\
(0.0138) \\
\end{array}$ & $\begin{array}{c}-0.07 \\
(0.0196)\end{array}$ \\
\hline $\mathrm{mmu}$ & $\begin{array}{c}0.22 \\
(0.1015)\end{array}$ & $\begin{array}{c}0.39 \\
(0.1429)\end{array}$ & $\begin{array}{c}0.00 \\
(0.0045)\end{array}$ & $\begin{array}{c}-0.02 \\
(0.0064)\end{array}$ \\
\hline mmu-miR-26a & $\begin{array}{c}0.52 \\
(0.2726) \\
\end{array}$ & $\begin{array}{c}0.95 \\
(0.3667)\end{array}$ & $\begin{array}{c}0.01 \\
(0.0116)\end{array}$ & $\begin{array}{c}-0.04 \\
(0.0164)\end{array}$ \\
\hline mmu-miR-296 & $\begin{array}{c}0.16 \\
(0.1484)\end{array}$ & $\begin{array}{c}0.53 \\
(0.2099)\end{array}$ & $\begin{array}{c}0.01 \\
(0.0066)\end{array}$ & $\begin{array}{c}-0.02 \\
(0.0094)\end{array}$ \\
\hline mmu-miR-330 & $\begin{array}{c}0.14 \\
(0.1657)\end{array}$ & $\begin{array}{c}0.64 \\
(0.2343)\end{array}$ & $\begin{array}{c}0.01 \\
(0.0074)\end{array}$ & $\begin{array}{c}-0.03 \\
(0.0105)\end{array}$ \\
\hline mmu-miR-193 & $\begin{array}{c}0.16 \\
(0.1961)\end{array}$ & $\begin{array}{c}0.72 \\
(0.273)\end{array}$ & $\begin{array}{c}0.01 \\
(0.0086)\end{array}$ & $\begin{array}{c}-0.03 \\
(0.0122)\end{array}$ \\
\hline
\end{tabular}

Table 6. Significant miRNA in Treatment and Interaction using Raw data. $\hat{\alpha}, \beta, \hat{Y}$ and $\hat{\eta}$ are the coefficient values of intercept, treatment, age, and age*treatment respectively. The values in parenthesis are the standard error values for the given coefficient. 


\begin{tabular}{|c|c|c|c|c|}
\hline NAME & $\begin{array}{c}\hat{\alpha} \\
(\mathrm{SE})\end{array}$ & $\begin{array}{c}\beta \\
\text { (SE) }\end{array}$ & $\begin{array}{c}\hat{Y} \\
\text { (SE) }\end{array}$ & $\begin{array}{c}\hat{\eta} \\
\text { (SE) }\end{array}$ \\
\hline mmu-miR-34c & $\begin{array}{c}3.81 \\
(0.2716)\end{array}$ & $\begin{array}{c}-1.01 \\
(0.3722)\end{array}$ & $\begin{array}{c}-0.018 \\
(0.0118)\end{array}$ & $\begin{array}{c}0.035 \\
(0.0166) \\
\end{array}$ \\
\hline mmu-miR-27a & $\begin{array}{c}4.43 \\
(0.4893) \\
\end{array}$ & $\begin{array}{c}-1.66 \\
(0.6079) \\
\end{array}$ & $\begin{array}{c}-0.024 \\
(0.0192) \\
\end{array}$ & $\begin{array}{c}0.074 \\
(0.0272)\end{array}$ \\
\hline mmu-miR-223 & $\begin{array}{c}0.56 \\
(0.1299) \\
\end{array}$ & $\begin{array}{c}0.62 \\
(0.1837) \\
\end{array}$ & $\begin{array}{c}0.001 \\
(0.0058) \\
\end{array}$ & $\begin{array}{c}-0.022 \\
(0.0082) \\
\end{array}$ \\
\hline mmu-miR-17-3p & $\begin{array}{c}0.38 \\
(0.1021)\end{array}$ & $\begin{array}{c}0.43 \\
(0.1426)\end{array}$ & $\begin{array}{c}0.001 \\
(0.0045)\end{array}$ & $\begin{array}{c}-0.017 \\
(0.0064)\end{array}$ \\
\hline mmu-miR-125a & $\begin{array}{c}0.31 \\
(0.0963) \\
\end{array}$ & $\begin{array}{c}0.32 \\
(0.1351) \\
\end{array}$ & $\begin{array}{c}0.002 \\
(0.0043) \\
\end{array}$ & $\begin{array}{c}-0.015 \\
(0.006)\end{array}$ \\
\hline mmu-miR-705 & $\begin{array}{c}0.67 \\
(0.2236)\end{array}$ & $\begin{array}{c}0.94 \\
(0.3103)\end{array}$ & $\begin{array}{c}0.001 \\
(0.0098)\end{array}$ & $\begin{array}{c}-0.035 \\
(0.0139)\end{array}$ \\
\hline mmu-miR-21 & $\begin{array}{c}0.31 \\
(0.1141) \\
\end{array}$ & $\begin{array}{c}0.56 \\
(0.1583) \\
\end{array}$ & $\begin{array}{c}0.005 \\
(0.005)\end{array}$ & $\begin{array}{c}-0.020 \\
(0.0071)\end{array}$ \\
\hline mmu-miR-216a & $\begin{array}{c}0.31 \\
(0.1219) \\
\end{array}$ & $\begin{array}{c}0.49 \\
(0.1701) \\
\end{array}$ & $\begin{array}{c}0.009 \\
(0.0054) \\
\end{array}$ & $\begin{array}{c}-0.019 \\
(0.0076) \\
\end{array}$ \\
\hline mmu- & $\begin{array}{c}0.31 \\
(0.1213)\end{array}$ & $\begin{array}{c}0.42 \\
(0.17) \\
\end{array}$ & $\begin{array}{c}0.006 \\
(0.0054)\end{array}$ & $\begin{array}{c}-0.017 \\
(0.0076)\end{array}$ \\
\hline mmu-miR-667 & $\begin{array}{c}0.73 \\
(0.3686) \\
\end{array}$ & $\begin{array}{c}1.89 \\
(0.4879)\end{array}$ & $\begin{array}{c}0.025 \\
(0.0154)\end{array}$ & $\begin{array}{c}-0.079 \\
(0.0218)\end{array}$ \\
\hline mmu-miR-26a & $\begin{array}{c}0.51 \\
(0.2647)\end{array}$ & $\begin{array}{c}0.89 \\
(0.3572)\end{array}$ & $\begin{array}{c}0.008 \\
(0.0113)\end{array}$ & $\begin{array}{c}-0.037 \\
(0.016) \\
\end{array}$ \\
\hline mmu-miR-137 & $\begin{array}{c}0.21 \\
(0.1213) \\
\end{array}$ & $\begin{array}{c}0.37 \\
(0.1715) \\
\end{array}$ & $\begin{array}{c}0.008 \\
(0.0054)\end{array}$ & $\begin{array}{c}-0.019 \\
(0.0077)\end{array}$ \\
\hline mmu-miR-701 & $\begin{array}{c}0.20 \\
(0.1455) \\
\end{array}$ & $\begin{array}{c}0.57 \\
(0.2006) \\
\end{array}$ & $\begin{array}{c}0.004 \\
(0.0063) \\
\end{array}$ & $\begin{array}{l}-0.021 \\
(0.009) \\
\end{array}$ \\
\hline mmu-miR-296 & $\begin{array}{c}0.15 \\
(0.1527) \\
\end{array}$ & $\begin{array}{c}0.54 \\
(0.216) \\
\end{array}$ & $\begin{array}{c}0.008 \\
(0.0068)\end{array}$ & $\begin{array}{c}-0.020 \\
(0.0096)\end{array}$ \\
\hline mmu-miR-330 & $\begin{array}{c}0.13 \\
(0.169) \\
\end{array}$ & $\begin{array}{c}0.69 \\
(0.2388) \\
\end{array}$ & $\begin{array}{c}0.011 \\
(0.0075) \\
\end{array}$ & $\begin{array}{c}-0.028 \\
(0.0107) \\
\end{array}$ \\
\hline mmu-miR-193 & $\begin{array}{c}0.15 \\
(0.2076) \\
\end{array}$ & $\begin{array}{c}0.79 \\
(0.289) \\
\end{array}$ & $\begin{array}{c}0.012 \\
(0.0091)\end{array}$ & $\begin{array}{c}-0.029 \\
(0.0129) \\
\end{array}$ \\
\hline
\end{tabular}

Table 7. Significant miRNA in Age and Interaction using Quantile Normalization. $\hat{\alpha}$, $\beta, \hat{Y}$ and $\hat{\eta}$ are the coefficient values of intercept, treatment, age, and age*treatment respectively. The values in parenthesis are the standard error values for the given coefficient. 


\begin{tabular}{|c|c|c|c|c|}
\hline NAME & $\begin{array}{c}\hat{\boldsymbol{\alpha}} \\
(\mathrm{SE})\end{array}$ & $\begin{array}{c}\hat{\boldsymbol{\beta}} \\
(\mathrm{SE})\end{array}$ & $\begin{array}{c}\hat{\mathbf{\gamma}} \\
(\mathrm{SE})\end{array}$ & $\begin{array}{c}\hat{\boldsymbol{\eta}} \\
(\mathrm{SE})\end{array}$ \\
\hline mmu-miR-669c & $\begin{array}{c}-0.09 \\
(0.1228)\end{array}$ & $\begin{array}{c}0.32 \\
(0.1737)\end{array}$ & $\begin{array}{c}0.02 \\
(0.0055)\end{array}$ & $\begin{array}{c}-0.02 \\
(0.0078)\end{array}$ \\
\hline mmu-miR-19b & 0.08 & 0.35 & 0.01 & -0.02 \\
& $(0.1412)$ & $(0.1937)$ & $(0.0061)$ & $(0.0087)$ \\
\hline mmu-miR-325 & 0.03 & 0.39 & 0.02 & -0.02 \\
& $(0.1438)$ & $(0.2015)$ & $(0.0064)$ & $(0.009)$ \\
\hline
\end{tabular}

Table 8. Significant miRNA in Age and Interaction using Raw data. $\hat{\alpha}, \hat{\beta}, \hat{Y}$ and $\hat{\eta}$ are the coefficient values of intercept, treatment, age, and age*treatment respectively. The values in parenthesis are the standard error values for the given coefficient. 


\section{CONCLUSIONS}

Three Normalization methods were used in this study: 1). Delta $\mathrm{Ct}$ method, 2). Rank invariant method and 3). Quatile normalization method. Among these three normalization methods for MicroRNA Microarray (MMchip) analysis, Delta $\mathrm{Ct}$ method and Rank invariant method does not work/apply because reference gene is used to normalize. Clearly we can see that Quantile normalization is the best normalization method for MM chip analysis because it does not use reference gene to normalize the raw data. This is the only method which can be used in both qPCR analysis and the MM chip analysis. Using the whole date we can figure that more miRNA's are significant. In the studies like this one it's always better to use all the repeated samples rather than just taking the averages of the repeated samples to avoid the error within the replicates. The study shows how to do the sample size calculation with repeated replicates. 


\section{REFERENCES}

1 He L, Hannon GJ. MicroRNAs: small RNAs with a big role in gene regulation. Nature reviews Genetics. 2004 Jul;5(7):522-31.

2 Khanna A, Muthusamy S, Liang R, Sarojini H, Wang E. Gain of survival signaling by down-regulation of three key miRNAs in brain of calorie-restricted mice. Aging. 2011 Mar;3(3):223-36.

3 Wang E, Lacelle C, Xu S, Zhao X, Hou M. Designer microarrays: from soup to nuts. The journals of gerontology Series A, Biological sciences and medical sciences. 2002 Nov;57(11):B400-5.

4 Statistical analysis of repeated microRNA high-throughput data with application to human heart failure: a review of methodology(Rai, Herman, Xiaobin, Jianmin, Tariq Hamid, Sumanth D ,2012).

5 Modern Applied Statistics with S-Plus(statistics and computing) 


\title{
CURRICULUM VITAE
}

\author{
VIKRANTH SHETTY \\ Email: v0shet01@cardmail.louisville.edu \\ Phone- 847-915-0694
}

\section{Current job :}

Statistical Research Assistant at Gheens centre on Aging-University of Louisville, Dept of Biochemistry.

Statistical Research Assistant at Advanced Genomic Technology Louisville, ky.

May 2011 till present

This research is for generating a blood based diagnostic for Alzheimer's disease. I will be responsible to conduct statistic analysis with the voluminous data generated from the various experiments leading to the goal of the project.

Work Experience in University of Louisville: June 2010 till present

Gain of survival signaling by down-regulation of three key miRNAs in brain of calorie-restricted mice. Aging (Albany NY). 2011 Mar;3(3):223-36

Role: Worked as a Research assistant

Description: Data analysis on the lab experimental data conducted on mice models and representing the analysed data with graphs/plots. Finding the miRNAs targets genes.

Environment: SAS, SPSS, MS EXCEL, RNA22, TARGET SCAN.

Post-transcriptional regulation of IGF1R by key microRNAs in long-lived mutant mice.

Aging Cell. 2011 Dec;10(6):1080-1088.

Role: Worked as a Research assistant

Description: Data analysis on the lab experimental data conducted on mice models and representing the analysed data with graphs/plots. Finding the miRNAs targets genes.

Environment: SAS, SPSS, MS EXCEL, RNA22, TARGET SCAN. 
Circulatory miR34a as an RNAbased, noninvasive biomarker for brain aging. Aging (Albany NY). 2011 Oct;3(10):985-1002.

Role: Worked as a Research assistant

Description: Data analysis on the lab experimental data conducted on mice models and representing the analysed data with graphs/plots. Finding the miRNAs targets genes.

Environment: SAS, SPSS, MS EXCEL, RNA22, TARGET SCAN.

Working on two more new scientific papers(forthcoming).

Internship at 'Divakar Multispeciality Hospital' $\quad$ Nov 2005 to Mar 2006

Project Title: A COMPARATIVE STUDY OF GESTATIONAL DIABETES MELLITUS (GDM) GROUP AND NON-GESTATIONAL DIABETES MELLITUS GROUP.

Thesis done at University of Louisville as part of Curriculum

Thesis Title: Analysis of MicroRNA Microarray (MM chip) data for Aging Mice models

Skills:

1 Knowledge of SAS, SPSS, MATLAB.

2 Proficient in Microsoft Word, Excel, Access, PowerPoint.

3 Excellent written and verbal communication skills.

\section{Education:}

Master of Science in Biostatistics University of Louisville - Kentucky

$2010-2012$

Bachelor of Science Osmania University - India

Major- Mathematics, Statistics and Computer Science

2003 to 2006 